FREITAS, João Paulo. Retrato do artista no jornal correio de Uberlândia: do mito do artista divino aos estereótipos contemporâneos da profissão. Domínios da Imagem, v. 12, n. 23, p. 68-90, jul./dez. 2018.

ISSN 2237-9126

\title{
RETRATO DO ARTISTA NO JORNAL CORREIO DE UBERLÂNDIA: DO MITO DO ARTISTA DIVINO AOS ESTEREÓTIPOS CONTEMPORÂNEOS DA PROFISSÃOI
}

\section{PORTRAIT OF THE ARTIST IN THE JORNAL CORREIO DE UBERLÂNDIA: FROM MYTH OF DIVINE ARTIST TO CONTEMPORARY PROFESSION STEREOTYPES}

Recebido em 29/9/2017 e aprovado em 30/11/2018

João Paulo de Freitas ${ }^{\bullet}$

Resumo: Este artigo apresenta as principais questões que nortearam um estudo sobre a relação entre retrato de artistas visuais e a formação de um imaginário sobre a profissão analisando como os retratos de artistas visuais divulgados no Jornal Correio de Uberlândia (MG), observando como as reproduções fotográficas dos artistas presentes neste jornal podem influenciar na formação ou manutenção de determinadas noções sobre a profissão do artista visual no contexto local. Para este exame são discutidos retratos de artistas em diferentes momentos da história do gênero e considerando as possibilidades específicas que o advento da fotografia criou na construção de uma imagem social dos artistas.

Palavras-chave: retratos de artistas. Estereótipos de artistas. Imaginários sobre artistas.

Abstract: This paper presents the main questions that guided a study about the relationship between portraiture of visual artists and the formation of an imaginary about the profession, analyzing how the portraits of visual artists published in the Jornal Correio de Uberlândia (MG), observing how photographic reproductions of artists present in this newspaper can influence the formation or maintenance of certain notions about the profession of visual artist in the local context. For his examination, it is discussed portraits of artists at different moments in the history of the genre and considering the specific possibilities that the advent of photography created in the construction of a social image of artists.

Keywords: portrait of artists. Stereotypes of artists. Imaginary about artists.

\footnotetext{
1 Dissertação desenvolvida no Programa de Pós-Graduação em Artes da Universidade Federal de Uberlândia sob o título: Artistas Visuais nos retratos fotográficos: da tradição aos retratos de artistas no Jornal Correio. Sob orientação da Profa.Dr. ${ }^{a}$ Lucina Mourão Arslan.

- Atualmente é doutorando no Programa de Pós-Graduação em Arte e Cultura Visual da UFG e bolsista CAPES sob orientação da Profa. Dr. ${ }^{a}$ Rosana Horio Monteiro.
} 
FREITAS, João Paulo. Retrato do artista no jornal correio de Uberlândia: do mito do artista divino aos estereótipos contemporâneos da profissão. Domínios da Imagem, v. 12, n. 23, p. 68-90, jul./dez. 2018.

ISSN 2237-9126

\section{Introdução}

O retrato de um artista pode ser tão importante quanto o conjunto de sua produção? A forma como um artista é representado pode apresentar aspirações profissionais destes indivíduos? Retratos de artistas são desenvolvidos apenas por meio de escolhas estéticas e técnicas ou também são orientadas por certas ideias sobre a profissão? Os retratos de artistas colaboram para construir uma identidade artística no imaginário social?

Estas são algumas das questões mais amplas que provocaram uma pesquisa sobre a relação entre retratos de artistas visuais e a construção da profissão no imaginário. Elegendo como objeto de estudo retratos de artistas, veiculados no jornal Correio principal periódico da cidade de Uberlândia (MG).

Considerando que toda representação é criada por meio de filtros culturais característicos e por isso impregnadas de ideais e valores, procuramos analisar de que maneira os retratos de artistas reproduzidos neste periódico atuavam na construção e manutenção de determinadas concepções consagradas sobre os artistas, sua personalidade e prática profissional.

Para compreender a prática do retrato e autorretrato de artistas, realizamos um breve panorama histórico de resgate de momentos em que os retratos de artistas demarcam identidades que caracterizam ainda hoje a profissão. Três momentos decisivos da modernidade cultural teriam fortes influências na forma como enxergamos os artistas: $O$ advento do artista moderno, a popularização da fotografia no século XIX e o fenômeno das celebridades na cultura de massa do século XX.

A partir do estudo de certos modelos consagrados, discutimos a relação entre o retrato, concepções e anseios sobre os artistas e sua profissão. Mais que um exercício técnico ou ilustrativo, o retrato de artistas firmaria um posicionamento frente aos demais grupos sociais: uma atitude de 
FREITAS, João Paulo. Retrato do artista no jornal correio de Uberlândia: do mito do artista divino aos estereótipos contemporâneos da profissão. Domínios da Imagem, v. 12, n. 23, p. 68-90, jul./dez. 2018.

ISSN 2237-9126

autoafirmação, que reivindicava um melhor posicionamento, destaque ou diferenciação perante outros grupos sociais.

Munidos deste repertório histórico e teórico partimos para o embate com as imagens do jornal Correio, elegendo como recorte temporal as fotografias de artistas visuais divulgadas a partir de 1993, ano de lançamento do caderno Revista, suplemento especializado em arte, cultura e cotidiano que, entre outras inovações gráficas, trazia sempre um retrato de artista local.

Entre os procedimentos metodológicos desenvolvemos uma pesquisa bibliográfica sobre o tema em questão, seleção de imagens a partir do acervo do centro de documentação do Arquivo Público de Uberlândia e entrevistas semiestruturadas com artistas e fotógrafos locais que atuaram ou foram retratados no periódico.

A seguir serão apresentados alguns conceitos principais que nortearam a pesquisa. Posteriormente serão apresentados alguns exemplos de retratos de artistas consagrados discutindo os aspectos que estas imagens propagam sobre a profissão. Finalizamos com uma análise geral das imagens de artistas no jornal Correio e tecemos considerações finais sobre a pesquisa.

\section{Retratos de artistas: Imaginários e construções sociais}

Esta pesquisa recorre inicialmente ao conceito de mito do artista, noção desenvolvida por Ernest Kris e Otto Kurz (KRIS; KURZ, 1988, p. 34), que ao investigarem as raízes das biografias de artistas destacaram a existência de alguns elementos característicos que descreviam suas vidas e processo de formação.

Como verdadeiros mitos estas noções estariam presentes em diversas concepções sobre o artista, mesmo os contemporâneos, que a princípio estariam desligados de noções menos essencialistas da profissão. 
FREITAS, João Paulo. Retrato do artista no jornal correio de Uberlândia: do mito do artista divino aos estereótipos contemporâneos da profissão. Domínios da Imagem, v. 12, n. 23, p. 68-90, jul./dez. 2018.

ISSN 2237-9126

O conceito de imaginário se apoia nas perspectivas de Gilbert Durand (DURAND, 2000, p. 331) que admitem uma modalidade simbólica universal para a imaginação e que parecem passíveis de diálogo com o mito do artista proposto por Ernest Kris e Otto Kurz.

Durand destaca que há duas formas para a consciência representar a realidade, uma seria diretamente onde a própria coisa parece estar presente na percepção ou na sensação, e outra, indireta, quando a coisa não pode se apresentar diretamente à sensibilidade, como no caso da recordação ou da imaginação. Nesse caso, aquilo que estaria ausente é "re-presentado" por meio de imagem.

O conceito de imagem de artista, em sentido amplo, faz referência à concepção socialmente compartilhada do que seja e o que faz um artista. Esta imagem destaca a forma como este sujeito é imaginado e construído enquanto indivíduo ou profissional. A relação desta imagem social com os retratos ocorre a partir da constatação de que imagens não são isentas das questões sociais e políticas dentro de seu espaço de produção e circulação.

Analisadas em sua visualidade, ou seja, como forma de olhar socializado, lugar de articulação entre discursividades e pretensões sociais, as imagens expõem uma complexa rede de construções, diálogos e apagamentos. Um estudo que considere as intricadas relações entre discursos, mentalidades e formas de representação demonstra como os retratos menos pretenciosos podem expor desejos, anseios e até fantasias sobre a profissão.

É neste sentido que Sergio Miceli (MICELI, 1996, p. 12-17), ao empreender um estudo sobre a produção de retratos do pintor Cândido Portinari, demonstra como o campo artístico não está isolado de questões sociais mais amplas, constituindo também um campo de batalha na disputa por poder. Para o autor, há uma negociação entre aqueles que 
FREITAS, João Paulo. Retrato do artista no jornal correio de Uberlândia: do mito do artista divino aos estereótipos contemporâneos da profissão. Domínios da Imagem, v. 12, n. 23, p. 68-90, jul./dez. 2018.

ISSN 2237-9126

representam e aqueles que são representados, agenciando vários aspectos da experiência social dos envolvidos.

Annateresa Fabris (FABRIS, 2004, P. 82) por sua vez, destaca o retrato como um gênero em que normas sociais e psicologia individual confrontamse em que o resultado é uma identidade conciliada como ideal social de si mesmo. Ou seja, a fotografia por meio do retrato constrói uma identidade social, padronizada, que desafia o conceito de individualidade, criando várias tipologias.

Em um estudo que analisou a invisibilidade das mulheres na arte brasileira por parte da crítica e da historiografia da arte em períodos anteriores à Semana de Arte Moderna de 1922, Ana Paula Cavalcanti Simioni (SIMIONI, 2008, P. 201-203) descreveu a trajetória da pintora Abigail de Andrade, autora de inúmeros autorretratos.

No levantamento de Simioni é significativa a importância dos retratos da artista como forma de identificar o processo de busca de afirmação pessoal e profissional, construindo através de sua própria imagem uma tentativa de equação com um universo intelectual e artístico marcadamente sexista guiado quase exclusivamente por homens.

A partir do exposto é possível observar como os retratos, além de apresentarem questões formais e estéticas, também podem ser vistos como a manifestação de negociações e embates entre a produção artística e questões sociais e culturais mais amplas.

A imagem, ao criar vínculos com as mitologias do artista, pode inclusive incorporar dilemas pessoais. Se lembrarmos, por exemplo, de Van Gogh e os episódios que marcam sua vida, é inevitável não trazer à tona o retrato com parte da orelha amputada. Ao falar de Van Gogh, o especialista poderá destacar os aspectos estéticos, artísticos e formais de sua produção bem como algumas imagens secundárias que permeiam o senso-comum e cujos retratos dos artistas também ajudam a construir. Alguns 
FREITAS, João Paulo. Retrato do artista no jornal correio de Uberlândia: do mito do artista divino aos estereótipos contemporâneos da profissão. Domínios da Imagem, v. 12, n. 23, p. 68-90, jul./dez. 2018.

ISSN 2237-9126

destes aspectos secundários são igualmente importantes na criação do mito do artista.

\section{A prática do retrato e autorretrato na pintura}

O surgimento e a consolidação da prática do retrato e do autorretrato dos artistas, seriam um reflexo direto das mudanças no estatuto social deste profissional. O desenvolvimento da modernidade cultural a partir do Renascimento Italiano, por volta do século XVI, teria reservado um estatuto intelectual especial para o artista. A este grupo social caberia uma individualidade intelectual, estilística e criativa carregada de uma aura mística divina, algo muito latente no autorretrato de Albrecht Dürer destacado a seguir (Imagem 1).

Imagem 1 - Albrecht Dürer. 1500. Pintura sobre painel, Tinta acrílica, Tinta a óleo.

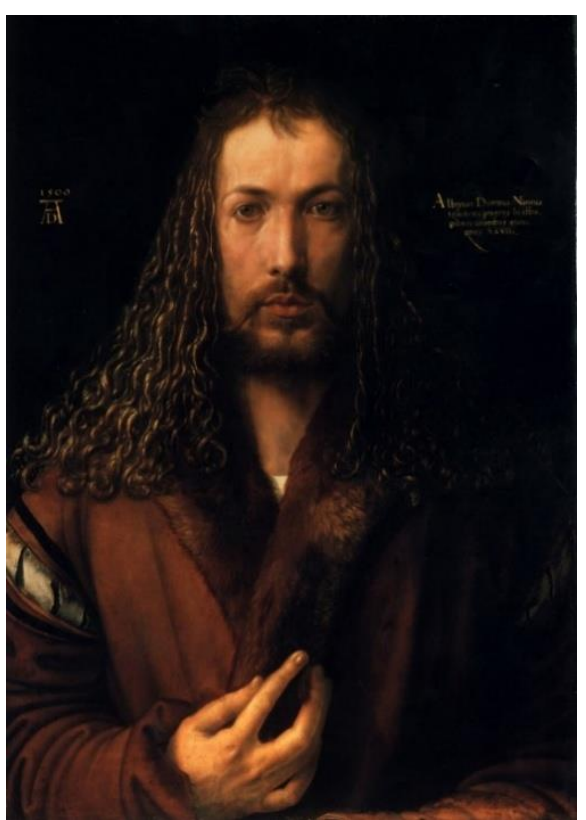

Fonte: Disponível em: http://www.albrecht-durer. Acessado em: 25 maio 2012.

Nos retratos e autorretratos, o artista ganha dignidade, fruto das mudanças na forma como a sociedade passa a enxergá-los. Contudo, a aura mística do artista, o gênio como "criador divino" ainda apresenta uma 
FREITAS, João Paulo. Retrato do artista no jornal correio de Uberlândia: do mito do artista divino aos estereótipos contemporâneos da profissão. Domínios da Imagem, v. 12, n. 23, p. 68-90, jul./dez. 2018.

ISSN 2237-9126

poderosa inserção no imaginário e a noção de gênio persiste até hoje, inclusive em algumas esferas "mais especializadas" da arte.

Nas imagens dos consagrados artistas acadêmicos do século XVII e XVIII, observamos a representação da dignidade intelectual, do polimento e das normas aristocráticas de conduta. A ênfase na razão e no humanismo trazem à tona a figura do artista com a dignidade esperada da instituição acadêmica a que está submetido.

Elementos designadores da profissão como objetos de trabalho, pincéis, godês e cavaletes, modelos clássicos para estudo, aparelhos de observação desenvolvem uma verdadeira cenografia para o artista erudito. O retrato de Charles Le Brum realizado por seu colega acadêmico Nicolas De Largilliere apresenta estas questões (Imagem 2).

Imagem 2 - Nicolas de Largilliere. Retrato de Charles Le Brun. 1686. Óleo sobre tela.

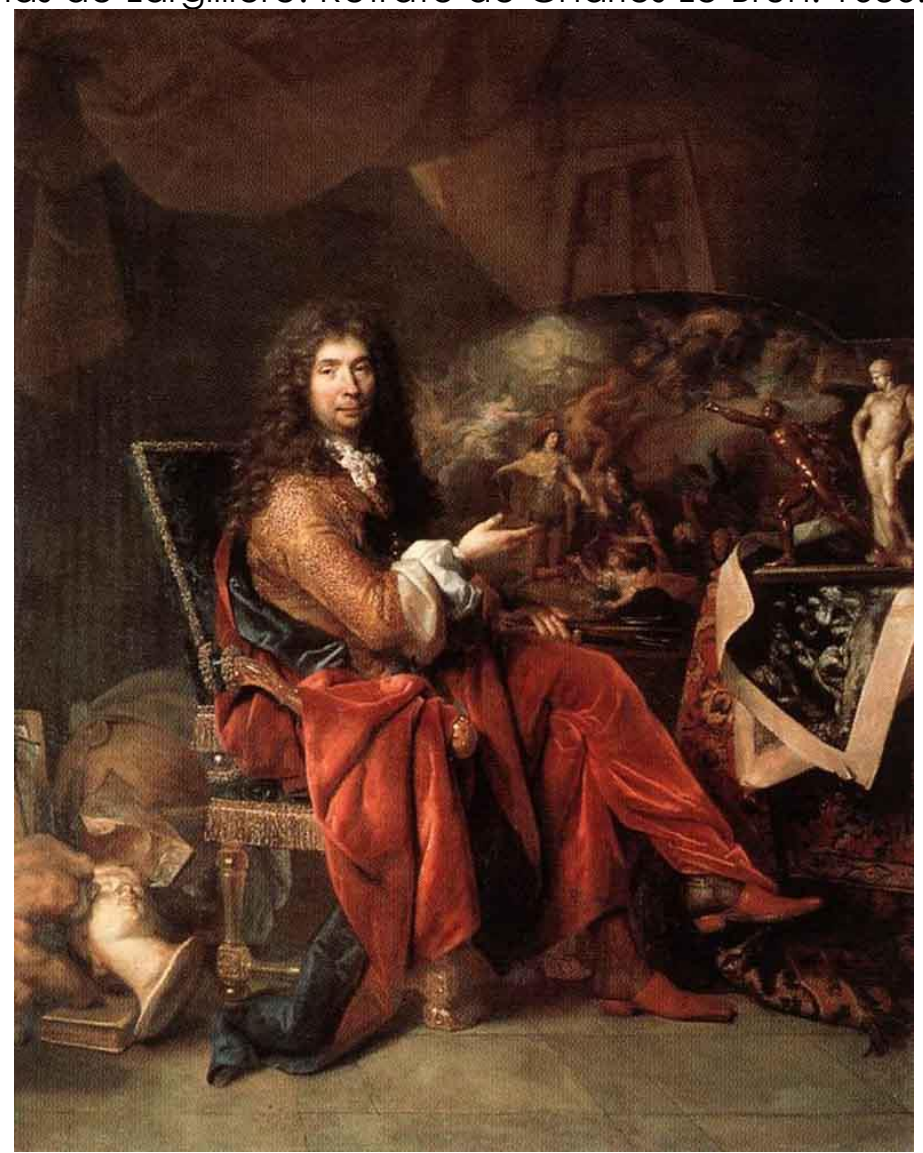

Fonte: Disponível em: www.lib-art.com. Acessado em: 6 jun. 2012. 
FREITAS, João Paulo. Retrato do artista no jornal correio de Uberlândia: do mito do artista divino aos estereótipos contemporâneos da profissão. Domínios da Imagem, v. 12, n. 23, p. 68-90, jul./dez. 2018.

ISSN 2237-9126

Retratos de artistas no século XIX: Os estereótipos representativos da profissão

A entrada em cena da fotografia no início do século XIX estabelece novos parâmetros artísticos e culturais para a arte e a sociedade. Em um primeiro momento, o gênero de retrato recorre a alguns códigos representativos da pintura incorporando padrões compositivos e até funções sociais.

O fotógrafo Étienne Carjat (1828 - 1906) oferece um exemplo significativo sobre a dependência da fotografia com algumas tradições pictóricas. Seu retrato do pintor Charles Daubigny (Imagem 3), retoma o modelo do artista caracterizado por seus instrumentos de trabalho. $O$ artista encontra-se em posse de suas ferramentas pincéis, godê, cavalete, tintas. As roupas e o chapéu são característicos e compõem um código visual que irá se tornar talvez a imagem mais estereotipada do artista visual.

Imagem 3 - Retrato do pintor Charles Daubigny. Fotografia: Étienne Carjat. Sem Data. 
FREITAS, João Paulo. Retrato do artista no jornal correio de Uberlândia: do mito do artista divino aos estereótipos contemporâneos da profissão. Domínios da Imagem, v. 12, n. 23, p. 68-90, jul./dez. 2018.

ISSN 2237-9126

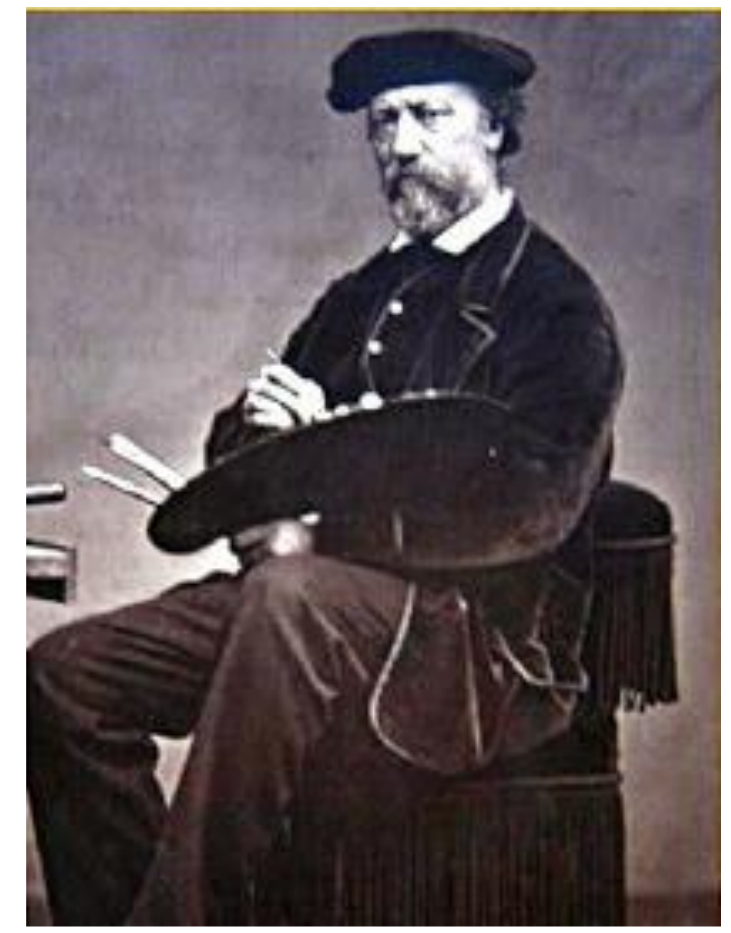

Fonte: Disponível em: http://www.daubigny.net. Acessado em: 22 mar. 2011.

O constante aperfeiçoamento e o barateamento no custo da

produção de fotografias permitiram a popularização do retrato entre classes menos abastadas. Como destaca Ana Maria Mauad (2005, p. 26).

O retrato fotográfico democratizou a imagem, antes limitada aos recursos da pintura. O barateamento dos custos, bem como a ampliação do número de fotógrafos itinerantes ao longo do segundo reinado, ampliam o mercado consumidor, configurando uma clientela cada vez mais heterogênea. Já não é raro, em fins do século XIX, encontrarem-se fotografias de ex-escravos, como também de um número cada vez maior de imigrantes pobres que utilizavam a fotografia como um meio de construir a sua própria posteridade.

O fotógrafo Eugéne Disdéri (Imagem 4) desenvolve os "portrait cartede-visite" pequenos retratos (dimensões $6 \times 9 \mathrm{~cm}$ ), que representavam os retratados dos pés à cabeça em um cartão de visitas. Devido ao baixo custo de realização, estas imagens podiam ser vendidas a preços módicos, o que gerou sua rápida popularização entre as camadas da pequena burguesia dos quais figuravam alguns profissionais liberais e artistas. 
FREITAS, João Paulo. Retrato do artista no jornal correio de Uberlândia: do mito do artista divino aos estereótipos contemporâneos da profissão. Domínios da Imagem, v. 12, n. 23, p. 68-90, jul./dez. 2018.

ISSN 2237-9126

Como destaca Gisèle Freund (FREUND, 2006, p. 36-39), a possibilidade de ter um retrato era um importante elemento simbólico de ascensão social, determinava que o sujeito retratado era minimamente digno de nota. Muitos artistas, recorriam aos Carte-de-visite e visando potencializar sua produção, Disdéri desenvolve uma sistematização de poses e cenários estereotipados baseados justamente nas profissões dos retratados.

Imagem 4 - Alguns retratos comerciais de Eugène Disdéri. (Da esquerda para a direita e de cima para baixo): Autorretrato de Disdéri, o ator Gueymard, o pintor Descamps, o sábio Ortolan, o escritor Paul d’Evoi. Aprox. 1850.

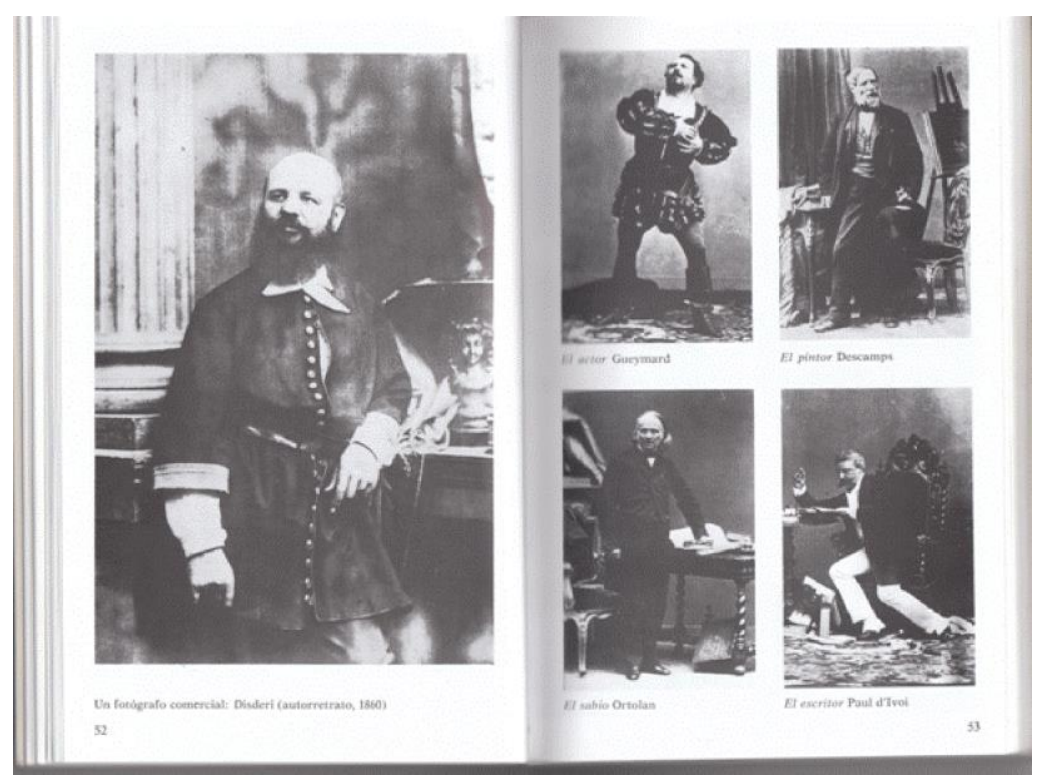

Fonte: Freund (2006, p. 35).

A tendências ao estereótipo nas representações, tem segundo Peter Burke (BURKE, 2004, p. 55-74) a função de mediação, "filtro" na relação com o outro, elegendo aspectos, informações e características que podemos 
FREITAS, João Paulo. Retrato do artista no jornal correio de Uberlândia: do mito do artista divino aos estereótipos contemporâneos da profissão. Domínios da Imagem, v. 12, n. 23, p. 68-90, jul./dez. 2018.

ISSN 2237-9126

aceitas na relação com o diferente. Para o autor, o estereótipo pode não ser completamente falso, mas frequentemente exagera alguns traços da realidade e omite outros. Assim, os estereótipos fotográficos sobre os artistas seriam o caminho seguro para mediar aquilo que socialmente é esperado do artista no século XIX, eliminando dissonâncias e contradições.

O estereótipo é um processo tão seguro na mediação social que é amplamente utilizado ainda hoje, sobretudo na mídia impressa. Guardando as devidas diferenças entre um Carte-de-visite e uma fotografia na atualidade, um exercício comparativo convida a pensar a existência de certos códigos dos primórdios da fotografia ainda hoje (Imagem 5).

Imagem 5 - Retrato da pintora Núbia Rocha. Autoria desconhecida. Data desconhecida. Imagem de arquivo.

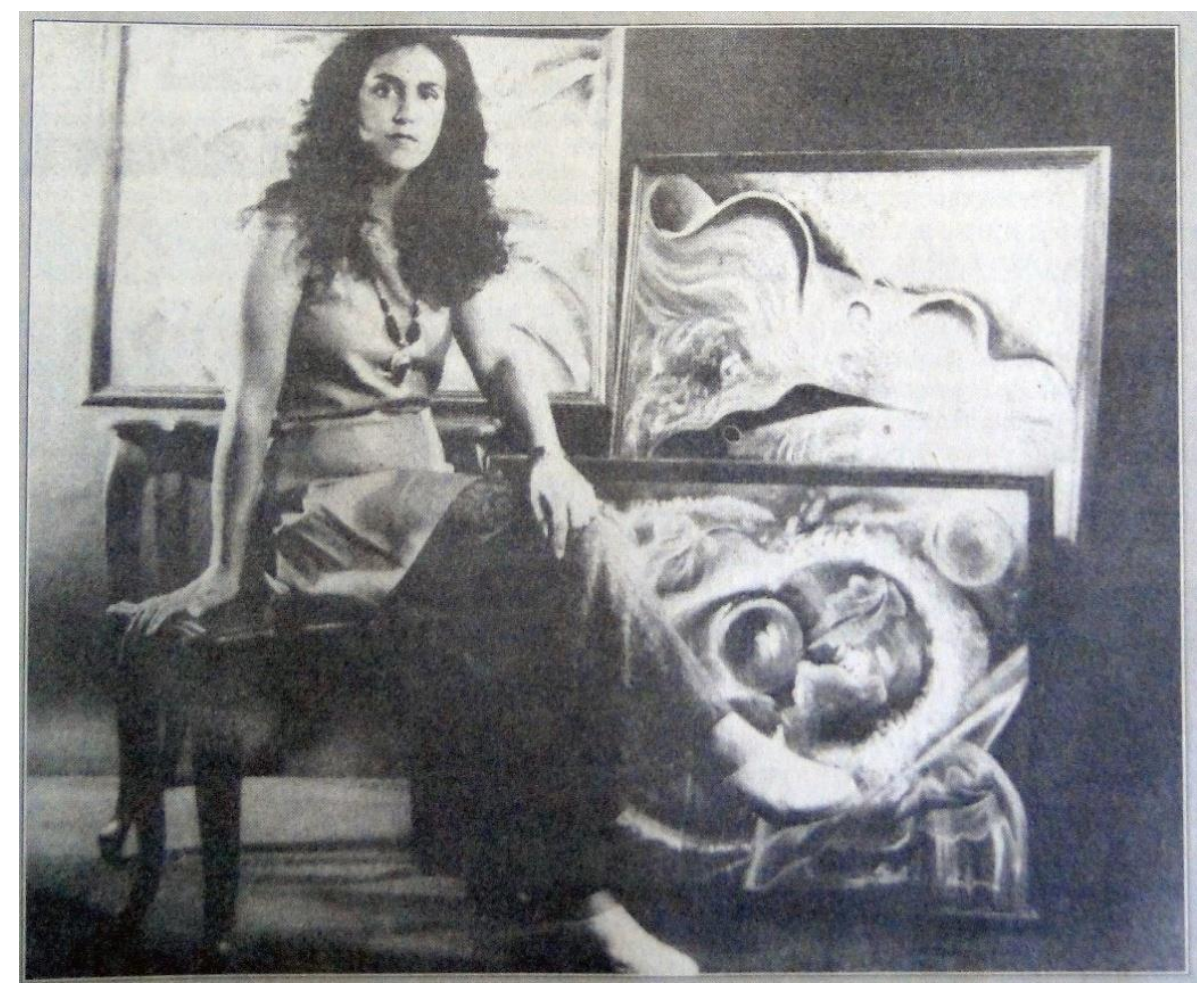

Fonte: Jornal Correio de Uberlândia. Caderno Revista. Edição de 26 de nov. 1994.

\section{Os retratos de artista como celebridade}


FREITAS, João Paulo. Retrato do artista no jornal correio de Uberlândia: do mito do artista divino aos estereótipos contemporâneos da profissão. Domínios da Imagem, v. 12, n. 23, p. 68-90, jul./dez. 2018.

ISSN 2237-9126

A partir do século XX, na visão de Jean Baudrillard (2007), observaríamos o surgimento de uma sociedade de consumo cada vez mais carregada de consumidores e ofertas. Neste contexto, destacar-se socialmente seria fundamental como forma de sobreviver diante da vasta oferta de produtos.

Á diferenciação e a consagração do artista como indivíduo peculiar, exótico e intelectualizado se torna uma forte orientação nos retratos de artista desde então. O desenvolvimento da indústria gráfica no início do século foi acompanhado de perto pelo emprego em massa de reproduções fotográficas. Seja por meio de jornais e revistas, o alcance social da imagem fotográfica toma imensas proporções, criando uma nova dimensão para os usos e funções da imagem dentro da cultura ocidental.

Em um mundo em que a comunicação é fortemente ancorada no visual, o lugar e o estatuto do artista no imaginário passariam inevitavelmente pela criação e manutenção de uma determinada imagem pública, construída em grande medida por sua representação visual.

Na segunda metade do século XX, alguns dos mais celebrados artistas como Salvador Dalí, Picasso ou Andy Warhol, posam para algum ensaio fotográfico em periódicos de grande circulação. Esta exposição era fundamental como forma de marcar o sucesso profissional ou mesmo criar uma imagem como parte de um jogo em que a própria imagem do artista compõe uma atitude performática frente ao público, a mídia e o próprio mundo da arte.

Neste contexto, a fotografia se estabelece como um território autônomo: muitos fotógrafos se tornaram ícones, geralmente profissionais que trabalhavam para grandes agências de notícias. Ocorre uma grande valorização da sua figura como artista e gênio perspicaz na arte e enquadrar, congelar momentos e criar registros por meio de uma forte sensibilidade do olhar. Fenômeno semelhante ao que levou o artista a se 
FREITAS, João Paulo. Retrato do artista no jornal correio de Uberlândia: do mito do artista divino aos estereótipos contemporâneos da profissão. Domínios da Imagem, v. 12, n. 23, p. 68-90, jul./dez. 2018.

ISSN 2237-9126

emancipar, o fotógrafo também vira jornalista, artista, cronista e passa a ser reconhecido como tal.

Esses profissionais acabam sendo os responsáveis por construir visualmente diversos ícones de uma cultura globalizada e cada vez mais ligada à imagem, as celebridades do cinema, da televisão, da música e também das artes visuais.

Criadores ou recriadores de novas mitologias, os ensaios fotográficos destes profissionais se tornaram célebres e acompanham até hoje camisetas, reproduções impressas, tatuagens, lembranças de museus, etc.

A importância de retratos como os realizados pelo fotógrafo Philippe Halsman sobre o pintor Salvador Dalí, estavam em explorar novas abordagens para o gênero, inclusive incorporavam elementos da própria estética do artista. A imagem social construída pelas imagens de Halsman sobre Salvador Dalí constituem um elemento tão importante que muitas vezes é quase impossível separar certas o trabalho do fotógrafo das obras do pintor. Como se retrato e obra fossem parte de um mesmo ato performático.

Imagem 6 - O bigode de Dalí. Fotografia: Phillipe Hausman. 1954.

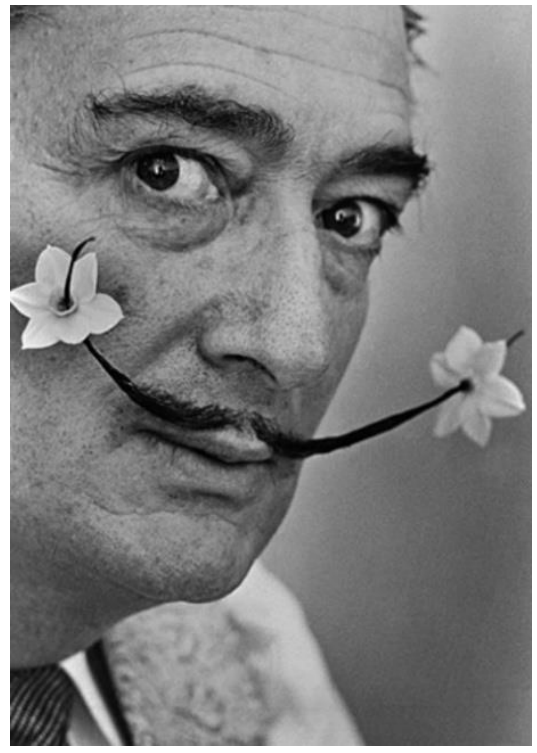

Fonte: Disponível em: philippehalsman.com. Acessado em: 14 abr. 2012. 
FREITAS, João Paulo. Retrato do artista no jornal correio de Uberlândia: do mito do artista divino aos estereótipos contemporâneos da profissão. Domínios da Imagem, v. 12, n. 23, p. 68-90, jul./dez. 2018.

ISSN 2237-9126

O relacionamento cada vez mais explícito entre retratos de artistas e imagem social é explorado como forma de modelar uma personalidade artística, caracterizando um personagem. Um exame crítico de alguns retratos, permite observar a forma como determinados modelos culturais são criados ou questionados não só pelas produções visuais de artistas, mas também pelas imagens secundárias que permeiam o campo da arte como é o caso do retrato.

\section{Os retratos de artistas no jornal Correio: visão geral e re-considerações metodológicos da pesquisa}

Para analisar os retratos de artistas publicados no jornal Correio, algumas considerações importantes merecem ser destacadas com relação às especificidades e características do veículo e do tipo de abordagem utilizada. Levando em conta o caráter da pesquisa, não consideramos nenhum tipo de levantamento quantitativo, como o número de vezes que determinado artista apareceu retratado, ou a repetição de padrões de pose. O interesse recaiu principalmente na seleção de exemplos e modelos de retratos que pareciam em consonância com os modelos destacados no levantamento bibliográfico e visual.

Também não foi nossa intenção promover uma leitura valorativa estética sobre as qualidades "artísticas" das imagens. O interesse era observar e tentar compreender modelos de representação dos artistas no interior do referido jornal. Procurando pensar como estas imagens eram 
FREITAS, João Paulo. Retrato do artista no jornal correio de Uberlândia: do mito do artista divino aos estereótipos contemporâneos da profissão. Domínios da Imagem, v. 12, n. 23, p. 68-90, jul./dez. 2018.

ISSN 2237-9126

construídas a partir da ótica do veículo, de seus fotógrafos, mas guiados por um imaginário característico sobre os artistas visuais.

O objetivo era apontar determinadas concepções comuns sobre a profissão do artista, que em virtude do tipo de veículo que se encontram representados colaboram com a construção de uma imagem social destes artistas no contexto da cidade de Uberlândia.

O fato de o jornal se constituir de um veículo de circulação e consumo diário, evidentemente reflete um processo de produção e elaboração que preze, sobretudo, pela rápida execução. Neste processo, não é incomum fórmulas de representação bem-sucedidas sejam empregadas como modelo para temas que são recorrentes.

Soma-se a este perfil o fato de que o emprego de imagens fotográficas em um jornal tem como um de seus fundamentos "ilustrar, amarrar e reforçar o sentido dos textos jornalísticos". Por isso, muitas destas imagens repetem-se mudando apenas o artista. Uma concepção préestabelecida, que parece ignorar qualquer possibilidade de espontaneidade criativa ou acasos.

São imagens de caráter imediatista que devem ser vistas e interpretadas de forma objetiva. Contudo, isso não isenta tais imagens de dialogar ou mesmo formular um imaginário sobre os artistas, pois elas formulam modelos e estereótipos que constroem, mesmo que de forma fragmentar, ideais socialmente compartilhados sobre a profissão.

Ao analisar as imagens, observa-se uma saturação em que o os desvios e variações ocorrem depois de períodos muito longos ou quando um novo fotógrafo surge. Mesmo assim, se observou que as imagens rapidamente recaem em repetições e padrões bem simplificados.

\section{Artistas no jornal Correio: Do intelectual ao descolado despretensioso}


FREITAS, João Paulo. Retrato do artista no jornal correio de Uberlândia: do mito do artista divino aos estereótipos contemporâneos da profissão. Domínios da Imagem, v. 12, n. 23, p. 68-90, jul./dez. 2018.

ISSN 2237-9126

Buscando diálogos entre as imagens do jornal Correio e os modelos de retratos de artistas consagrados, analisando similitudes e ponto em comum destacamos que a aparente banalidade das imagens veiculados no Correio, podem trazer importantes reflexões sobre modelos e estereótipos que em conjunto criam narrativas de representações que podem habitam o imaginário social e o repertório visual da grande maioria dos leitores.

Um exemplo deste tipo de comparação pode ser visto na imagem a seguir, onde dispomos um famoso retrato do pintor Jackson Pollock e uma fotografia do pintor Vladimir Machado divulgada no jornal Correio. $\mathrm{Na}$ imagem, Pollock aparece despojado, com calça jeans e jaqueta de couro, os braços e pernas cruzados, apoiado na parede com olhar desafiador, soturno, quase um bad boy. Toda esta imagem irá compor a ideia uma narrativa sobre Pollock.

Imagem 7 - Jackson Pollock estampando matéria da revista Life Magazine.

Fotografia: Arnold Newman. 1949.

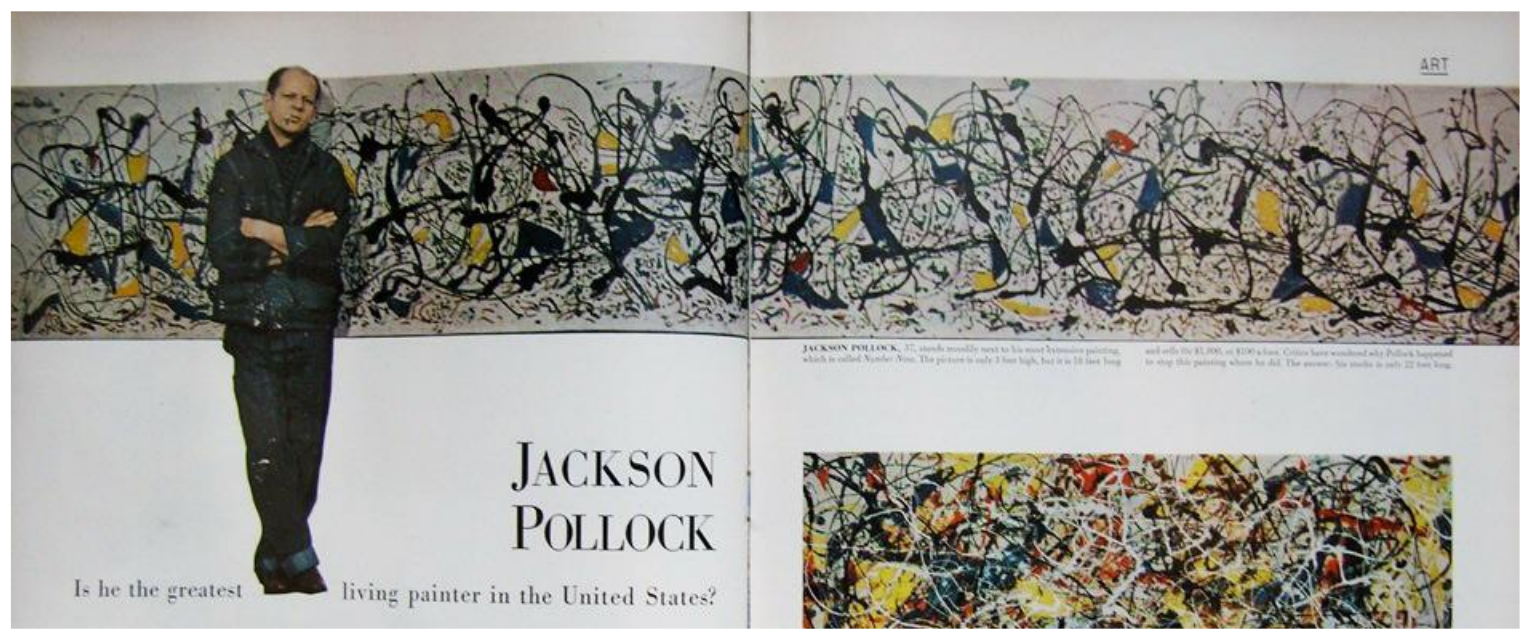

Fonte: Disponível em: ikono.org. Acessado em: 13 mar. 2012.

O artista incorpora o tipo rebelde encontrando grande aceitação por parte do público e passando a habitar o imaginário comum de forma 
FREITAS, João Paulo. Retrato do artista no jornal correio de Uberlândia: do mito do artista divino aos estereótipos contemporâneos da profissão. Domínios da Imagem, v. 12, n. 23, p. 68-90, jul./dez. 2018.

ISSN 2237-9126

irremediável. Este fato se deve em grande medida aos fotógrafos e aos veículos que criam e ajudam divulgar tal imagem.

Ao percorrer as páginas do jornal Correio nos deparamos com casos no mínimo curiosos como, por exemplo, um retrato do pintor Vladimir Machado (Imagem 8) que na imagem posa ao lado de um de seus trabalhos. Um olhar descuidado poderia sugerir uma pequena coincidência. Será que tal eco se dá por um jogo do acaso? Ou será que tais modelos visuais de representação dos artistas já estão tão incorporados a ponto de serem naturalizados tanto pelos artistas quanto pelos meios de disseminação da arte?

Imagem 8 - Vladimir Machado "Um Artista redescobre Pompéia em pinturas".

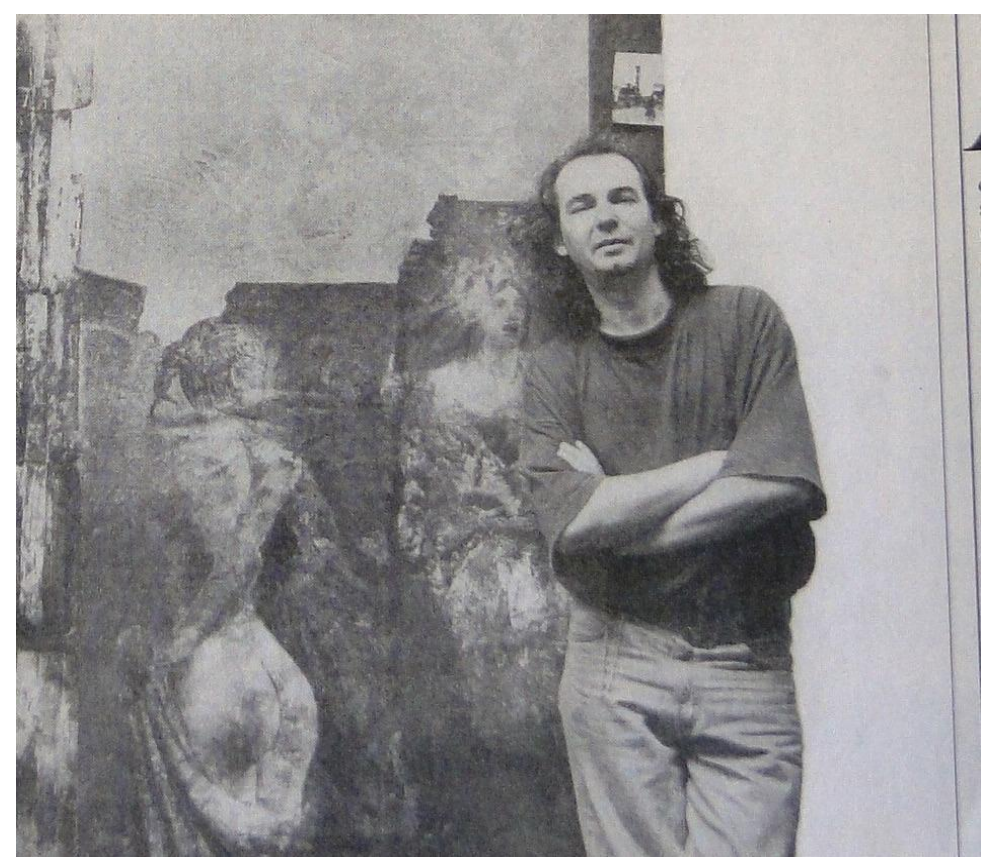


FREITAS, João Paulo. Retrato do artista no jornal correio de Uberlândia: do mito do artista divino aos estereótipos contemporâneos da profissão. Domínios da Imagem, v. 12, n. 23, p. 68-90, jul./dez. 2018.

ISSN 2237-9126

Fonte: Fotografia: (Imagem de arquivo) Jornal Correio. Edição de terça-feira. 13 nov. 1994. p.20

A posição dos braços e pernas cruzados, a cabeça inclinada, o olhar inquiridor. O quadro ao fundo, visivelmente uma pintura abstrata, posicionada ao fundo da mesma forma que a imagem de Pollock.

Outra abordagem possível é localizar no conjunto das imagens do jornal a construção de uma verdadeira narrativa para determinado artista.

Assis Guimarães é um conhecido artista da cidade e representado inúmeras vezes no periódico. Analisando o conjunto de retratos do artista podemos imaginar e construir a narrativa de uma vida livre, descontraída, irreverente, porém muitas vezes introspectivo e misteriosa.

Como exemplo podemos observar um retrato em que o artista aponta e dirige o olhar para algum ponto na câmera ou além dela (Imagem 9). Estaria apontando uma de suas pinturas? Talvez aquela região distante, que só os artistas conseguem alcançar com o poder de sua imaginação. 0 artista foi enquadrado de muito perto, sua mão está tão próxima que perdeu o foco. A imagem provoca o observador, tira ele da zona de conforto das publicidades e das imagens distantes e afastadas do resto do jornal. É uma imagem provocativa ou provocativo é o pintor?

Imagem 9 - Assis Guimarães. 
FREITAS, João Paulo. Retrato do artista no jornal correio de Uberlândia: do mito do artista divino aos estereótipos contemporâneos da profissão. Domínios da Imagem, v. 12, n. 23, p. 68-90, jul./dez. 2018.

ISSN 2237-9126

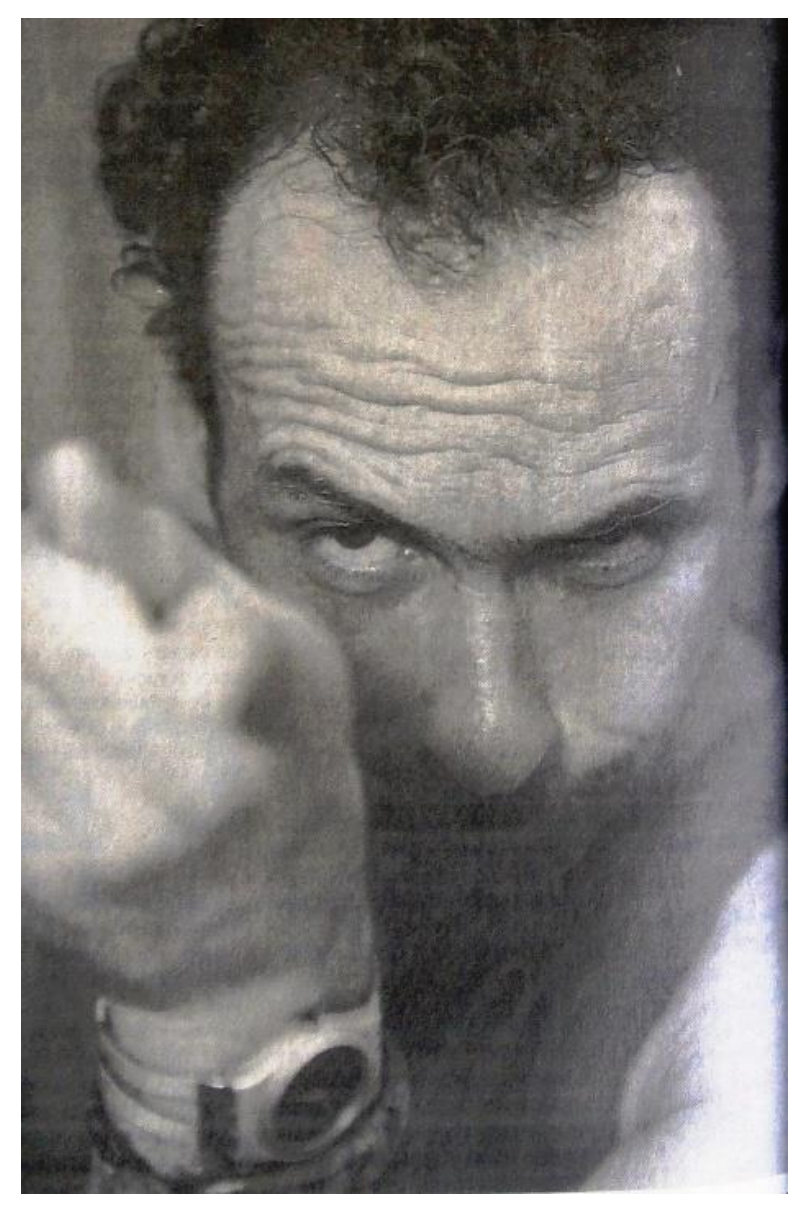

Fotografia: Roberto Chacur.

Fonte: O olhar enigmático de Assis Guimarães que comemorou mais um aniversário. Jornal Correio. Caderno Revista. Edição de 3 jan. 2002. p. D2.

Em outra imagem em particular (Imagem 11) o retrato do artista demonstra um momento peculiar e curioso: um passeio em uma motocicleta com seu cão, carregando uma grande pasta que possivelmente acomoda alguns de seus trabalhos. A situação aparentemente absurda e improvável confere inevitavelmente uma imagem de irreverência e excentricidade ao personagem bon-vivant do artista.

Imagem 11: Assis Guimarães. Fotografia: (imagem de arquivo). 
FREITAS, João Paulo. Retrato do artista no jornal correio de Uberlândia: do mito do artista divino aos estereótipos contemporâneos da profissão. Domínios da Imagem, v. 12, n. 23, p. 68-90, jul./dez. 2018.

ISSN 2237-9126

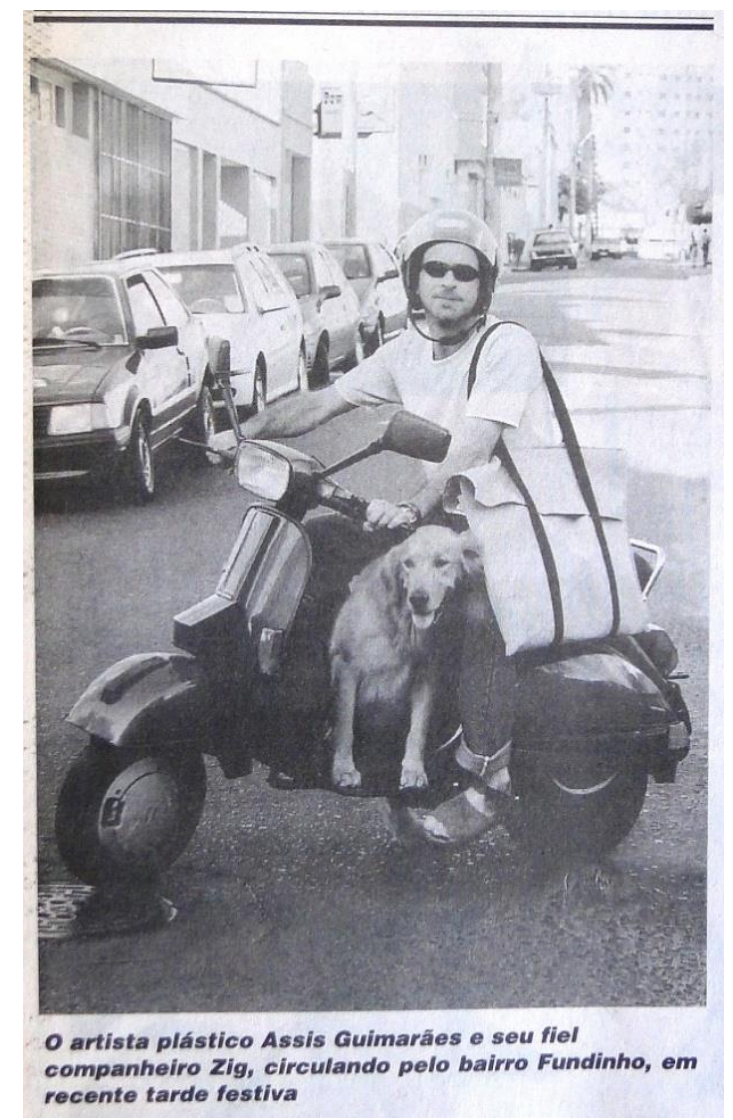

Fonte: $O$ artista plástico Assis Guimarães e seu fiel companheiro Zig. Jornal Correio. Caderno Variedades. Edição de sexta-feira. 13 nov. 1994. p.20.

A ausência formalidades, bem como outros códigos de distinção característico de outras profissões, não servem para desconstruir sua imagem profissional, mas para firmar ainda mais seu compromisso com a rotina livre, autônoma e criativa esperada dos artistas.

Se, para muitas pessoas, ter uma fotografia despojada publicada em um jornal seria um motivo de desqualificação profissional, esta construção imagética do artista caminha em sentido contrário sendo uma verdadeira conformação com o que dele é esperado.

De forma geral a imagem de Assis Guimarães é o protótipo do artista livre, irreverente e misterioso. Imagem característica de uma concepção que procura destacar a singularidade do artista que incorporaria em seu cotidiano um ideal de contracultura possível e admitido num horizonte de possibilidades conservadoras. O artista no imaginário se torna um desvio das 
FREITAS, João Paulo. Retrato do artista no jornal correio de Uberlândia: do mito do artista divino aos estereótipos contemporâneos da profissão. Domínios da Imagem, v. 12, n. 23, p. 68-90, jul./dez. 2018.

ISSN 2237-9126

concepções ordinárias da vida comum e do mundo do trabalho mesmo que faça parte dela no seu cotidiano.

A representação dos artistas é um fator fundamental para entender as concepções sobre estes profissionais em qualquer época. Da mesma forma que os textos críticos, documentais e historiográficos informam e caracterizam os artistas em diferentes contextos culturais, as imagens realizadas pelos próprios artistas ou pelos fotógrafos designados para representá-los também contribuem para a criação, manutenção ou crítica da imagem dos artistas no imaginário social.

Percebemos como a imagem do artista se sustenta sobre determinados elementos que o colocam em um lugar de distinção perante outros indivíduos, incorporando, em grande medida, uma concepção quase mítica destes profissionais em diálogo com a ideia dele como um herói ou portador de poderes divinatórios.

\section{Considerações finais}

Com relação à análise mais específica sobre a imagem do artista na mídia impressa local, foi possível perceber o emprego de determinados modelos que caracterizam certos padrões consagrados de representação destes profissionais. Algumas destas concepções, como averiguadas, remetem inclusive a certos ideais aparentemente anacrônicos sobre a profissão.

No jornal Correio, existem alguns elementos que se repetem constantemente na representação destes artistas. Considerando a função das imagens no interior do jornal como mediadora da comunicação entre o texto escrito e o leitor, a padronização de certas fórmulas de retrato, tidas como objetivas e diretas podem ser vistas como uma pasteurização da imagem do artista, limitando as concepções sobre seu trabalho e papel social. 
FREITAS, João Paulo. Retrato do artista no jornal correio de Uberlândia: do mito do artista divino aos estereótipos contemporâneos da profissão. Domínios da Imagem, v. 12, n. 23, p. 68-90, jul./dez. 2018.

ISSN 2237-9126

Por outro lado, o jornal tem o mérito de ser um dos únicos espaços da região a divulgar e apresentar a cultura e a produção artística local, sendo inclusive o maior arquivo de imagens de artistas da cidade.

Com relação aos artistas, percebemos que estes também não se preocupam muito com estas questões, não se enxergando como partes de um jogo de construção coletiva e entendendo a sua posição neste espaço como neutra ou indiferente. Esquecem assim que seus retratos também são criados e produzem significado. Desta forma, naturalizam uma posição e uma imagem social que nem sempre compactuam.

O retrato de artista é tudo menos uma mera formalidade. O campo da arte e da imagem também é local de disputa de poder. O fato da maioria dos jovens artistas guardar seu retrato no jornal é a confirmação de que finalmente seu trabalho está sendo reconhecido e nisto há uma grande relação entre as imagens fotográficas de hoje e os cartões de visitas do século XIX.

Vários destes retratos, como já destacado, muitas vezes serão os únicos registros de um dado momento histórico, cultural e artístico da cidade de Uberlândia. Desta forma, os retratos, as representações visuais dos artistas, assim como os discursos sobre esta profissão, devem ser discutidas, debatidos e analisados como forma de compreender a complexidade da cultura e sua relação com as imagens.

Talvez, a contribuição desta pesquisa seja apresentar novas questões que podem se desdobrar em pesquisas futuras. O levantamento geral sobre os retratos de artistas apresentou um grande número de fotógrafos brasileiros e estrangeiros que poderiam servir para um estudo mais específico, que pensasse a produção destes profissionais em seus contextos culturais. Neste caso, sobretudo os fotógrafos especializados em retratar artistas e celebridades, pois ainda são raras as análises que destacam a importância do trabalho destes fotógrafos na cultura ocidental. 
FREITAS, João Paulo. Retrato do artista no jornal correio de Uberlândia: do mito do artista divino aos estereótipos contemporâneos da profissão. Domínios da Imagem, v. 12, n. 23, p. 68-90, jul./dez. 2018.

ISSN 2237-9126

Por fim, uma possibilidade igualmente promissora sobre a análise das imagens de artistas é verificar os processos de resistência de fotógrafos ou artistas na criação de uma imagem ao empregar determinados códigos de representação como forma de se alinharem as concepções vigentes ou de subverterem sua lógica.

\section{Referências}

BURKE, Peter. Testemunha ocular: história e imagem. Bauru: EdusC, 2004.

DURAND, Gilbert. A imaginação simbólica. Lisboa: Edições 70, 2000.

FABRIS, Annateresa. Identidades virtuais: uma leitura do retrato fotográfico. Belo Horizonte: Editora UFMG, 2004.

FREUND, Gisèle. La fotografia como documento social. Barcelona: G.Gilli, 2006.

JORNAL CORREIO. Arte. Jornal Correio, Uberlândia-MG, 3 set. 1993. Social. p. 14.

Variedades. p. 7.

Arte. Uberlândia-MG, 20 set. 1993. Caderno de Assis expõe hoje. Jornal Correio, Uberlândia-MG, 6 abr. 1994. p. 16.

. Olhar enigmático de Assis Guimarães. Jornal Correio, Uberlândia-MG, 3 jan. 2002. Caderno Revista. P. D2.

- Olha a arte, fresquinha a preço de ocasião. Jornal Correio. Uberlândia-MG, 14 dez. 1993. Caderno Revista. p. 13.

- Pintura desenterra uma nova Pompéia. Jornal Correio. Uberlândia-MG, 13 set. 1994. Caderno Revista. p. 15.

. Variedades. Jornal Correio. Uberlândia-MG, 13 nov. 1994.

p.20.

KRIS, Ernest; KURZ, Otto. Lenda, Mito e Magia na Imagem do Artista: Uma experiência histórica. Lisboa: Editorial Presença, 1988. 
FREITAS, João Paulo. Retrato do artista no jornal correio de Uberlândia: do mito do artista divino aos estereótipos contemporâneos da profissão. Domínios da Imagem, v. 12, n. 23, p. 68-90, jul./dez. 2018.

ISSN 2237-9126

MAUAD, Ana Maria. Entre retratos e paisagens: modos de ver e representar no Brasil oitocentista. In: MARCONDES, Neide Marcondes; BELLOTO, Manuel (Org.). Turbulência cultural em cenário de transição: O século XIX iberoamericano. São Paulo: Editora da Universidade de São Paulo, 2005.

MICELI, Sergio. Imagens Negociadas: retratos da elite brasileira (1920-40). São Paulo: Companhia das Letras, 1996.

SIMIONI, Ana Paula Cavalcanti. Profissão Artista: Pintoras e escultoras Acadêmicas Brasileiras. São Paulo: Editora da Universidade Federal de São Paulo: FAPESP, 2008. 